\title{
Editorial
}

\section{Acid rain: time for Britain to act}

In June, as the British Government's Environment Committee was still investigating acid rain, the Nature Conservancy Council (NCC) published a report, Acid deposition and its implications for nature conservation in Britain.

The evidence reviewed is startling in its paucity: not much attention has been paid to the effects of acid rain on natural habitats in Britain.

Sufficient evidence exists, however, to support the view that concern about acidification in Britain is well-founded. The subject has engaged the attention of conservationists relatively recently; for a long time acid rain was believed not to be a particular problem in the UK. Unlike Scandinavia and North America, Britain was not faced with the visible drama of dying forests and fishless lakes. Nevertheless, acid deposition, of which the main cause is believed to be emissions of sulphur dioxide and nitrogen oxides from power stations, has been proceeding. Its effects have prompted Wildlife Link, the liaison body for all the major organisations in the UK concerned with wildlife conservation, to set up an Acid Rain Group, on which ffPS is represented.

The habitats most at risk in Britain are in upland areas, where the acid load in the rain is a heavy burden. In lowland areas of easily-weathered rock and rich soils the buffering system of the soil neutralises the excess acid easily. But the buffering capacity of poor soils on granite is quickly exhausted; the result-acid water drainage into upland streams and lakes. It is not the higher acidity alone that creates problems for organisms: aluminium is released from the soil at high acidity levels and is particularly toxic to fish.

The most outstanding change in acidified waters is an impoverishment of the flora and fauna, most dramatically the loss of fish. In the south of Scotland, an area of particular concern, many lakes and streams have acidity levels at which salmonid fish populations are stressed or become extinct, and toxic levels of aluminium. Of particular concern is the disappearance of rare species of fish; for example, genetically-isolated strains of char Salvelinus alpinus found in Galloway seem especially vulnerable. They have disappeared from Loch Grannoch and are Editorial threatened in Loch Doon. Animals dependent on aquatic prey appear to be suffering too: it is suggested that food losses attributable to acid deposition are at least partly responsible for declines in numbers of dippers Cinclus cinclus and otters in Scotland.

This and other evidence, which includes that of damage to plants and to prime lichen sites, indicates that serious ecosystem disturbances are taking place. One of the most disturbing conclusions in the report is that because of the uncontrollable effects of acidification the NCC should carefully consider the acquisition of upland sites as nature reserves, for it might be impossible to maintain their scientific interest. Liming can reverse some of the acidification trends, but it is only recommended in a few cases involving species protection.

No wonder that the NCC report concludes that the only long-term solution is to reduce the emissions of sulphur and nitrogen compounds. In North America, lakes near a smelting works have shown a remarkable recovery in response to a significant decrease in sulphur emissions. It could happen in Britain too, if the Government acts in time. It is certainly under great pressure to do so from its European neighbours, to which it is unwittingly exporting enormous quantities of airborne pollutants; outside the USSR the UK is the largest single producer of sulphur dioxide in Europe. Britain would do well to abandon its present isolationist policy and follow the example of Sweden, Norway, Denmark, Finland, West Germany, Austria, Switzerland, the Netherlands, France and Canada, who met in Ottawa in March and formed the Club of Thirty, each nation committing itself to reduce sulphur emissions by at least 30 per cent in the next 10 years and taking steps to reduce nitrogen oxide emissions.

The draft EEC directive, which seeks a 60 per cent reduction in emissions of sulphur dioxide from large plants by 1995, will come into effect in 1987. It would be prudent if Britain were to act before then, both to put her poor record straight and to save some of the finest wildlife sites left in Britain - and in other parts of Europe. 